\title{
Characterisation of natural fibre reinforced PLA foams prepared by supercritical $\mathrm{CO}_{2}$ assisted extrusion
}

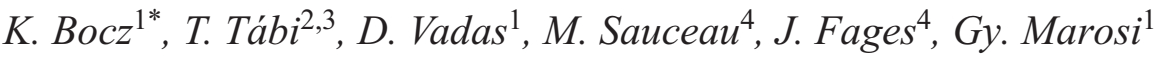 \\ ${ }^{1}$ Department of Organic Chemistry and Technology, Budapest University of Technology and Economics, Müegyetem rkp. 3., \\ H-1111 Budapest, Hungary \\ ${ }^{2}$ MTA-BME Research Group for Composite Science and Technology, Müegyetem rkp. 3., H-1111 Budapest, Hungary \\ ${ }^{3}$ Department of Polymer Engineering, Budapest University of Technology and Economics, Múegyetem rkp. 3 ., H-1111 \\ Budapest, Hungary \\ ${ }^{4}$ Centre RAPSODEE, École des Mines d'Albi, CNRS, Université de Toulouse, F-81013 Albi, France
}

Received 30 January 2016; accepted in revised form 19 April 2016

\begin{abstract}
Natural fibre reinforced polylactic acid (PLA) foams, as potential green replacements for petroleum-based polymer foams, were investigated. Highly porous $(\varepsilon>95 \%)$ microcellular PLA foams were manufactured by supercritical $\mathrm{CO}_{2}$ assisted extrusion process. To overcome the inherently low melt strength of PLA, epoxy-functionalized chain extender was applied, while talc was added to improve its crystallization kinetics. The combined application of chain extender and talc effectively promoted the formation of uniform cell structures. The effect of cellulose and basalt fibre reinforcement on the foamability, morphology, structure and mechanical properties of the PLA foams were investigated as well. The addition of $5 \mathrm{wt} \% \mathrm{natural}$ fibres promoted the cell nucleation, but caused non-uniform distribution of cell size due to the microholes induced by local fibre-matrix debonding. The compression strength of the manufactured basalt fibre reinforced PLA foams reached $40 \mathrm{kPa}$.
\end{abstract}

Keywords: biopolymers, biocomposites, foam extrusion, polylactic acid, natural fibre

\section{Introduction}

The replacement of conventional petrol-based and short life-cycle polymer foams with bio-based and biodegradable alternatives will be crucial for the natural environment and to diminish the burden of landfills, still the application of biopolymers as porous materials is negligible up to now.

Recently, poly(lactic acid) (PLA) foams have been considered as the most promising bio-based and biodegradable substitutes for polystyrene (PS) and polyethylene (PE) foam products, which currently hold the majority ratio in the packaging industry. This is mainly due to the competitive material and processing costs of PLA accompanied with comparable barrier and mechanical properties and environmental friendly character [1]. Besides packaging industry, there is a wide range of potential application fields for PLA foams, such as construction and transportation, where these could effectively serve as lightweight heat and sound insulating elements, panels and sandwich composite cores. However, to produce low-density PLA foams with uniform cell morphology, improvements of the inherent shortcomings of PLA, especially its low melt strength and slow crystallization kinetics, need to be addressed.

One of the most investigated methods to improve the melt strength of PLA is the increase of its molecular weight and the modification of its linear molecular structure by using chain extenders (CEs). CEs have two or more functional groups such as hydroxyl, amine, anhydride, epoxy, carboxylic acid or isocyanate. Bifunctional CEs couple the two end groups

$\overline{{ }^{*} \text { Corresponding author, e-mail: kbocz@mail.bme.hu }}$ (C) BME-PT 
of PLA, thereby lead to a linear polymer with somewhat higher molecular weight, while CEs of higher functionality give raise to branched structures with significantly improved rheological properties $[2,3]$. It was found by Wang et al. [4] that molecular branching increases melt strength and elasticity, and thereby also the integrity of cells, cell density, and expansion ratio during extrusion foaming.

Enhancing crystallization kinetics of PLA during foaming has been recognized as an effective way to overcome its weak viscoelastic properties and to improve its foaming behaviour (i.e. cell nucleation and expansion) $[1,5,6]$. In PLA, improved crystallinity has been achieved by using different nucleation agents, such as talc, that increase the heterogeneous nucleation density [7]. It was shown by Pilla et al. [2] that the simultaneous addition of talc and CE leads to increased cell density and more uniform cell structure. Fillers, such as wood particles [8] or clay nanoparticles [9] are also known to act as crystal nucleating agents and change the melt viscosity. Moreover fillers influence the microstructure and thus the mechanical and thermal properties of the foams [10]. Significant crystallinity can also be achieved by using plasticizers that widen the crystallization window by increasing the PLA chain mobility and decreasing the glass transition temperature.

Polymer foams are generally obtained by the addition of chemical blowing agents, their mostly exothermic reaction makes, however, the process and the final cell structure hardly controllable. In addition, they may lead to unwanted residues in the bulk. Physical blowing agents are more desirable from this respect. Currently, the focus is on $\mathrm{CO}_{2}$ due to its chemical inertness, non-flammability, relative ease of handling, well controllable influence and more favourable interaction with polymers compared to other inert gases. Moreover, it advantageously replaces less ecological solvents like butane, pentane or chlorofluorocarbons (CFCs), which are known for their contribution to the depletion of the ozone layer and may bring hazardous risks. Therefore, the new types of bio-foams are preferably manufactured by $\mathrm{CO}_{2}$ aided techniques.

Microcellular PLA foams can be manufactured through batch processes, which are, however, hardly scalable from lab-scale due to their small production rate. In the industry more cost-effective continuous processing technologies such as extrusion foaming and foam injection moulding are preferred. Recently, many studies have focused on extrusion foaming using supercritical $\mathrm{CO}_{2}\left(\mathrm{scCO}_{2}\right)$ as physical blowing agent [11]. When $\mathrm{CO}_{2}$ is supercritical, its solubility and diffusivity in PLA increases significantly. The $\mathrm{scCO}_{2}$ introduced into the extruder dissolves in the polymer melt and acts as a plasticizer [12] and by this means affects its crystallization rate [13]. Moreover, lower processing temperatures are applicable and also the mechanical abrasion of the equipment will be reduced. In addition, this may lead to reduced degradation of thermo-labile molecules like active pharmaceutical ingredients which may be used with such process [14]. Compared to the conventional foaming processes, the advantages of the $\mathrm{scCO}_{2}$ aided extrusion foaming are the accurate control of the foam quality (i.e. cell structure), the mild conditions (reduced risk of thermal and hydrolytic degradation), environmental friendliness (organic solventfree, no residue), the reduced energy demand during processing and the safety.

In this work, natural fibre reinforced PLA foams, as potential green replacements for petroleum-based polymer foams, were investigated. High porosity, microcellular biocomposite foams were manufactured by continuous $\mathrm{scCO}_{2}$ assisted extrusion process. To obtain uniform cell structures with increased cell density, epoxy-functionalized CE and talc were applied. The effect of cellulose and basalt fibre reinforcement was investigated on the morphology and mechanical properties of the PLA foams.

\section{Materials and methods}

\subsection{Materials}

Ingeo ${ }^{\mathrm{TM}}$ Biopolymer $3052 \mathrm{D}$ grade PLA $\left(T_{\mathrm{m}}=145-\right.$ $160^{\circ} \mathrm{C}, M_{\mathrm{w}}=116000 \mathrm{~g} / \mathrm{mol}, \mathrm{MFR}=14 \mathrm{~g} / 10 \mathrm{~min}$ $\left(210^{\circ} \mathrm{C}, 2.16 \mathrm{~kg}\right), \mathrm{D}$-lactide content $\left.=4 \%\right)$, purchased from NatureWorks LLC (Minnetonka, MN, USA), was the polymer matrix. Its rheology was controlled using a styrene-acrylic oligomer multi-functional epoxide chain extender (CE), Joncryl ADR4368-C with a molecular weight of $6800 \mathrm{~g} / \mathrm{mol}$ and an epoxy equivalent weight of $285 \mathrm{~g} / \mathrm{mol}$, kindly supplied by BASF SE (Lugwigshafen, Germany). As nucleating agent HTPultra5 L type talc (T), received from IMI FABI SpA (Postalesio, Italy), with a median diameter of $0.65 \mu \mathrm{m}$ was used. The applied reinforcements 
included cellulose fibres (Arbocel BWW40, J. Rettenmaier \& Söhne GmbH, Rosenberg, Germany) with average fibre length and diameter of 200 and $20 \mu \mathrm{m}$, respectively, and basalt fibres (Basaltex KVT 150tex13-I) with linear density of 150 tex, filament diameter of $13 \mu \mathrm{m}$ and an initial fibre length of $10 \mathrm{~mm} . \mathrm{CO}_{2}$ (Linde AG, Munich, Germany) was applied as physical foaming agent.

\subsection{Sample preparation}

Before processing, all materials (PLA, natural fibres and additives) were dried at $85^{\circ} \mathrm{C}$ for $6 \mathrm{~h}$ in all cases. PLA mixtures were prepared by using a Labtech Scientific LTE 26-44 modular twin screw extruder (Labtech Engineering Co., Samutprakarn, Thailand) with a constant screw speed of $20 \mathrm{rpm}$ and the following temperature profile of the extruder zones: zone $_{1}=175^{\circ} \mathrm{C}$, zone $2=175^{\circ} \mathrm{C}$, zone $_{3}=180^{\circ} \mathrm{C}$, zone $_{4}=180^{\circ} \mathrm{C}$, zone $_{5}=185^{\circ} \mathrm{C}$, zone $_{6}=190^{\circ} \mathrm{C}$. The obtained extrudates were pelletized and dried prior to foam extrusion. The composition of the manufactured four types of PLA compounds is summarised in Table 1.

Supercritical- $\mathrm{CO}_{2}$-aided melt extrusion was performed on a single-screw extruder (Rheoscam, SCAMEX, Crosne, France) with a screw diameter of $30 \mathrm{~mm}$ and a length to diameter ratio $(L / D)$ of 37 $[15,16]$. As physical foaming agent, $\mathrm{CO}_{2}$ was injected into the barrel using a syringe pump (260D, ISCO
Lincoln, NE, USA). As it is shown in Figure 1, the injection position is located at $20 \mathrm{~L} / D$ from hopper, where the screw diameter is constant. $\mathrm{CO}_{2}$ was introduced at the same pressure as the pressure prevailing in the extruder. The polymer- $\mathrm{CO}_{2}$ mixture then passed through a static mixer (SMB-H 17/4, Sulzer, Switzerland). This element, inserted before the die, provides a distributive mixing between the two components. A flat die with a width of $30 \mathrm{~mm}$ and an adjustable height, which allows tuning the pressure before the die, was used. The temperature inside the barrel was regulated at the following six locations: $T_{1}$ and $T_{2}$ before and $T_{3}$ after the $\mathrm{CO}_{2}$ injection location, $T_{4}$ before the mixing element, $T_{5}$ at the static mixer and $T_{6}$ at the die. The temperature $\left(T_{\text {mat } 1}-T_{\text {mat3 } 3}\right)$ and pressure $\left(P_{1}-P_{4}\right)$ of the material were measured at three and four sensor locations, respectively.

During foam extrusion experiments, the screw speed was kept constant at $30 \mathrm{rpm}$ and the following temperature profile was set for the extruder zones: $T_{\text {hopper }}=$ $50^{\circ} \mathrm{C}, T_{1}=160^{\circ} \mathrm{C}, T_{2}=180^{\circ} \mathrm{C}, T_{3}=180^{\circ} \mathrm{C}, T_{4}=$ $160^{\circ} \mathrm{C}$, while the mixer $\left(T_{5}\right)$ and die temperatures $\left(T_{6}\right)$ were varied at each experiments while keeping them at a same value. This temperature will be called die temperature in the rest of this article. $\mathrm{CO}_{2}$ was introduced at a constant volumetric flow rate ranging between 1.5 and $3.0 \mathrm{~mL} / \mathrm{min}$. Once $\mathrm{scCO}_{2}$ was injected, a significant decrease in the material pressure within the extruder barrel occurred, mainly due to the

Table 1. Composition of the PLA compounds used for foam extrusion

\begin{tabular}{|l|c|c|c|c|c|}
\hline \multicolumn{1}{|c|}{ Sample } & $\begin{array}{c}\text { PLA } \\
{[\mathbf{w t} \%]}\end{array}$ & $\begin{array}{c}\text { Chain extender } \\
{[\mathbf{w t} \%]}\end{array}$ & $\begin{array}{c}\text { Talc } \\
{[\mathbf{w t} \%]}\end{array}$ & $\begin{array}{c}\text { Cellulose fibre } \\
{[\mathbf{w t} \%]}\end{array}$ & $\begin{array}{c}\text { Basalt fibre } \\
{[\mathbf{w t} \%]}\end{array}$ \\
\hline PLA & 100 & - & - & - & - \\
\hline PLA+CE+T & 96 & 2 & 2 & - & - \\
\hline PLA+CE+T+CF & 91 & 2 & 2 & 5 & - \\
\hline PLA+CE+T+BF & 91 & 2 & 2 & - & 5 \\
\hline
\end{tabular}

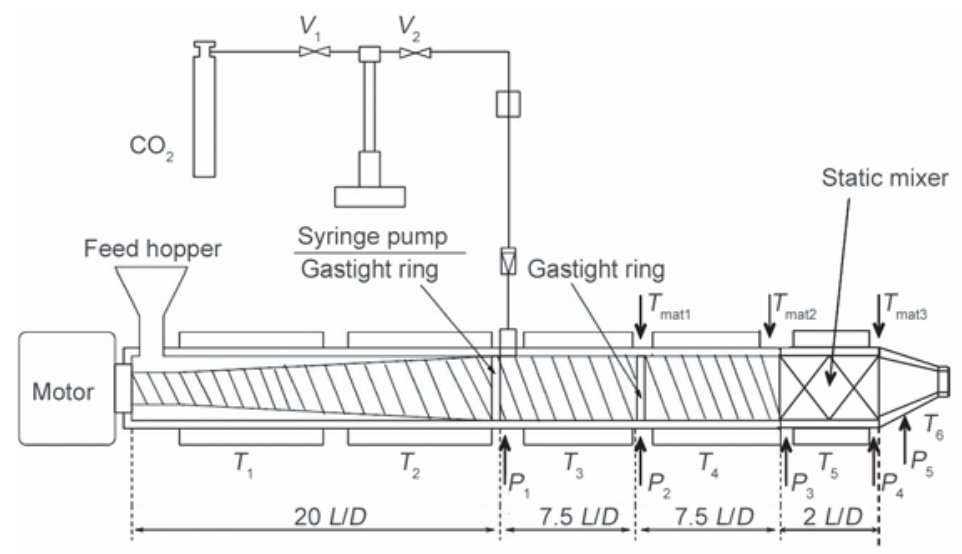

Figure 1. Schematic picture of the foaming system 
decrease of melt viscosity. Parallel with the increasing $\mathrm{CO}_{2}$ concentrations (in the range of 2 to $8 \mathrm{wt} \%$ ), $T_{5}$ and $T_{6}$ had been cooled to increase melt strength at the die. Once stable conditions have been established, samples were collected. At each new condition, the temperature $\left(T_{\text {mat3 } 3}\right)$ and pressure $\left(P_{4}\right)$ of the material, measured just before the entry within the die, were registered. To study the influence of operating parameters on porous structure, several experiments have been carried out varying mixer and die temperatures and $\mathrm{CO}_{2}$ concentration, by keeping other parameters constant.

\subsection{Methods}

\section{Rheological measurements}

Melt rheology under dynamical shear was investigated using an AR 2000 type rotational rheometer (TA Instruments, New Castle, DE, USA) with $25 \mathrm{~mm}$ diameter parallel-plate geometry. Dynamic frequency sweep tests were performed at $170^{\circ} \mathrm{C}$ to measure the complex shear viscosity $(\eta *, P a \cdot s)$ over a frequency range of $0.1-100 \mathrm{~Hz}$ under controlled strain of $1 \%$.

\section{Porosity measurements}

Porosity is defined as the ratio of void volume to the total volume of the foam sample. Porosity $(\varepsilon)$ of foams was calculated from their apparent density $\left(\rho_{\text {app }}\right)$ and the density of the non-foamed extrudate $(\rho)$ according to Equation (1):

$$
\varepsilon[\%]=100-\frac{\rho_{\text {app }}}{\rho} \cdot 100
$$

The bulk density $(\rho)$ of the PLA based polymer mixtures were considered to be $1.27 \mathrm{~g} / \mathrm{cm}^{3}$, while $\rho_{\text {app }}$ of expanded samples was determined by water-pycnometry.

\section{Scanning electron microscopy (SEM)}

Scanning electron microscopic (SEM) images were taken using a JEOL JSM-5500 LV type apparatus (JEOL Ltd., Akishima, Tokyo, Japan) using an accelerating voltage of $15 \mathrm{keV}$. The samples were coated with gold-palladium alloy before examination to prevent charge build-up on the surface.

\section{Differential scanning calorimetry (DSC)}

DSC measurements were carried out using a TA Instruments Q2000 type instrument (New Castle, DE,
USA) with a heating rate of $10^{\circ} \mathrm{C} / \mathrm{min}$ under $50 \mathrm{~mL} / \mathrm{min}$ nitrogen gas flow, covering a temperature range of $25-180^{\circ} \mathrm{C}$. About $3-6 \mathrm{mg}$ of sample was used in each test.

The percentage crystallinity $\left(\chi_{c}\right)$ of PLA foams was calculated according to Equation (2), where $\Delta H_{\mathrm{m}}$ is the melting enthalpy, $\Delta H_{\mathrm{cc}}$ is the cold crystallization enthalpy, $\Delta H_{\mathrm{m}}^{0}$ is the melting enthalpy of a perfect PLA crystal equal to $93 \mathrm{~J} / \mathrm{g}$ [16] and $\varphi$ is the weight fraction of fillers:

$\chi_{\mathrm{c}}[\%]=\frac{\Delta H_{\mathrm{m}}-\Delta H_{\mathrm{cc}}}{\Delta H_{\mathrm{m}}^{0} \cdot(1-\varphi)} \cdot 100$

\section{Compression strength}

An AR2000 Rheometer (TA Instruments, New Castle, DE, USA) with plate-plate adjustment was used for mechanical characterization of cylindrical foam specimens with a diameter of $8 \mathrm{~mm}$. Compression tests were carried out with a constant compression rate of $30 \mu \mathrm{m} / \mathrm{s}$. The diameter of the squeezing upper plate was $25 \mathrm{~mm}$ and the initial gap was $20 \mathrm{~mm}$ in all cases. The compressive resistance at $10 \%$ relative deformation were determined for each foam samples. At least 5 specimens were tested in all cases.

\section{Results and discussion}

\subsection{Rheological properties}

The effect of the used additives, chain extender, talc and fibres on the melt rheology and processability of PLA was studied by dynamic viscosity measurements. As illustrated in Figure 2, the introduction of $2 \% \mathrm{CE}$ and $2 \%$ talc was found to increase the complex viscosity. Likely, not only the CE induced long-

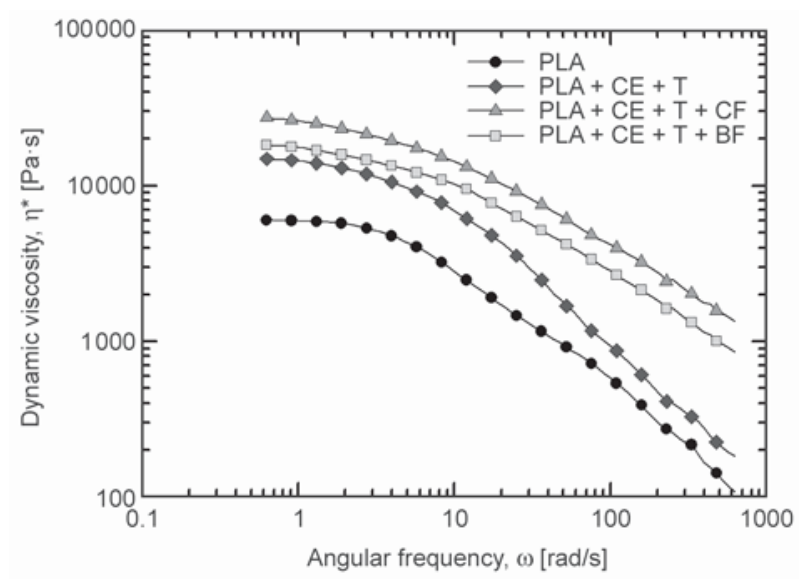

Figure 2. Dynamic viscosity as a function of angular frequency for neat and additive containing PLA 
chain branched structure reduced the chain mobility of PLA but also talc enhanced the melt viscosity mainly at the lower shear rate region. The addition of both cellulose and basalt fibres further increased the melt viscosity in the whole frequency range. As the increase of the viscosity mainly depends on the concentration, particle size, particle size distribution and shape of the fillers, the mobility of PLA chain segments were more hindered by the larger number, smaller and less uniform cellulose particles. The decreased chain mobility was expected to improve the melt strength and resistance against $\mathrm{CO}_{2}$ diffusion, but affect the crystallization kinetics as well.

\subsection{Morphology}

Foamed samples from each experiment were compared at three porosity levels, at around 15, 45 and $95 \%$, respectively. Highly porous $(\varepsilon>95 \%)$ PLA foam structures were obtained typically at a $\mathrm{CO}_{2}$ concentration of about $8 \mathrm{wt} \%$ and with $T_{\text {mat3 }}$ of around $110-120^{\circ} \mathrm{C}$, as presented in Figure 3. In all cases, the lower the die temperature, the higher the porosity. This effect is well documented in the literature [7] and is linked with the formation of a skin at the surface of the samples due to lower die temperatures and an optimal melt temperature before the die. This frozen surface prevents $\mathrm{CO}_{2}$ to escape leading to pore growth and higher expansion ratio. Moreover, in order to prevent cell coalescence and to preserve the high cell density, the polymer melt should be cooled substantially to increase its strength to preserve the high cell density, while keeping a sufficient fluidity for bubbles to grow. The effect of $\mathrm{CO}_{2}$ content is also linked with temperature since the $\mathrm{CO}_{2}$ solubilisation is inversely proportional to temperature. $\mathrm{High} \mathrm{CO}_{2}$ content can only be obtained at low temperatures.

It was observed that a wider processing window is available for PLA foam formation by using natural fibres. Compared to neat PLA, in the case of the additive containing mixtures less porous foams were obtained at all die temperatures, indicating more gas loss when CE, talc and fibre are present in the polymer melts. As a function of decreasing temperatures, a sharp increase in the porosity of the $\mathrm{CE}$ and talc containing PLA foam (PLA $+\mathrm{CE}+\mathrm{T}$ ) is observable, which is associated with its accelerated solidification with crystallization at low temperature. Similar behaviour was observed for the cellulose containing

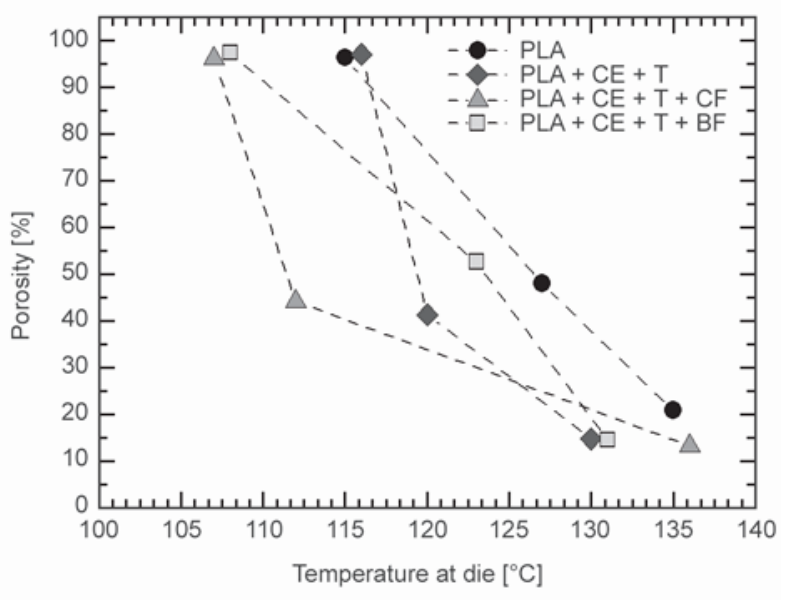

Figure 3. Effect of formulation and mixer and die temperatures on the porosity of PLA foams extruded at $8 \%$ of $\mathrm{CO}_{2}$

mixture, indicating enhanced nucleation effect of the dispersed cellulose fibres.

SEM micrographs taken from the highly expanded $(\varepsilon>95 \%)$ foams are presented in Figure 4. It can be seen that broad cell size distribution accompanied with rather limp or collapsed cell walls are characteristic for the neat PLA foam (Figure 4a). It is assumed that due to the early homogeneous nucleation the cells have longer time for growth [17]. Nevertheless, due to the insufficient melt strength of PLA at the foaming temperature, the cell walls have only low resistance against $\mathrm{CO}_{2}$ diffusion from the melt to the atmosphere, and thus limp and mechanically weak cell structure is formed. In contrast, the PLA foam containing $\mathrm{CE}$ and talc $(\mathrm{PLA}+\mathrm{CE}+\mathrm{T})$ had a denser and more uniform cell morphology (Figure $4 b$ ), indicating that the addition of $\mathrm{CE}$ effectively increased the melt strength. Based on the lower temperature profile, allowed in the case of the fibre reinforced foams, a greater degree of crystallinity and improved melt strength were expected. It can be seen on Figure 4c and $d$ that the addition of natural fibres resulted in decreased cell diameters likely due to the increased melt viscosity (see Figure 2) and due to the increased number of nucleating sites induced by the fibre surfaces $[18,19]$. At the same time, the fibre reinforced foams have less uniform cell structure, which should be related to the fibre distribution within the polymer matrix and the fibre matrix interactions [19]. It is suggested that as a result of local fibre-matrix debonding microholes are induced, where the gas loss hinders the cell growing ability, and thus non-uniform 


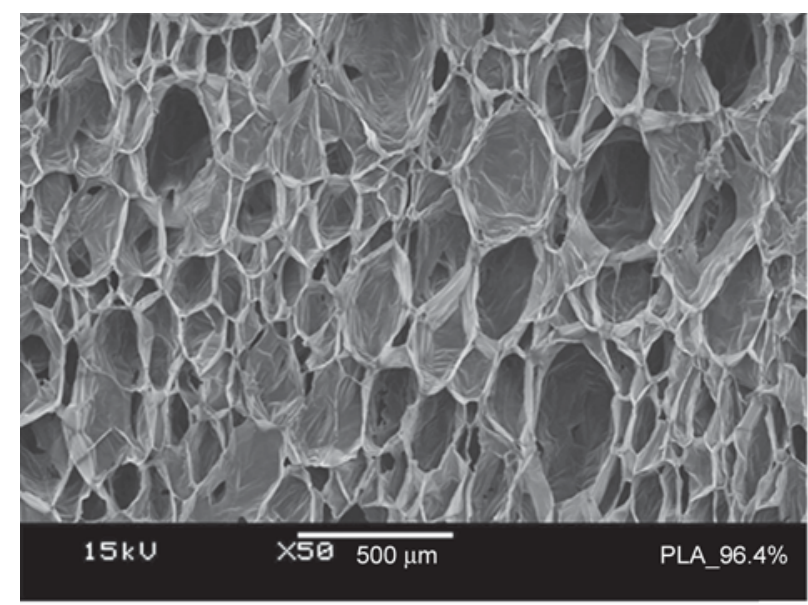

a)

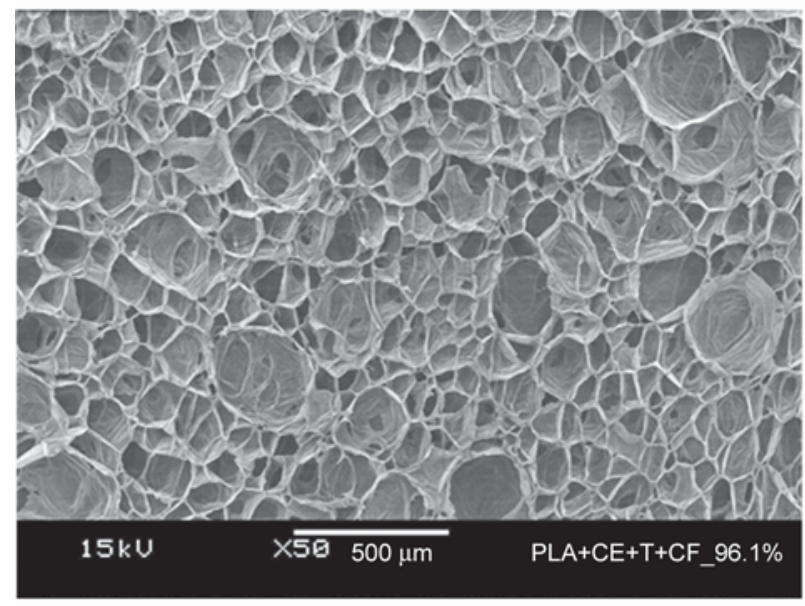

c)

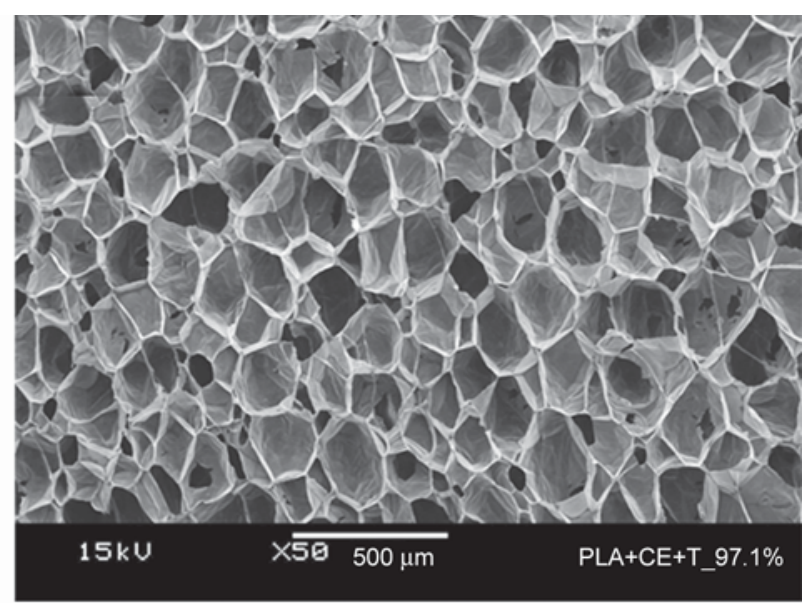

b)

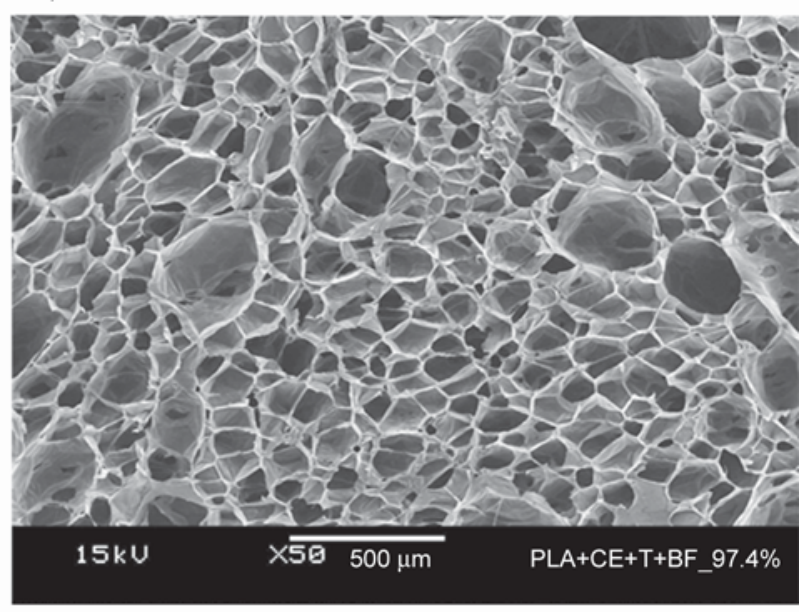

d)

Figure 4. SEM micrographs of the cell morphologies obtained for highly expanded ( $\varepsilon>95 \%$ ) PLA foams. PLA (a), $\mathrm{PLA}+\mathrm{CE}+\mathrm{T}(\mathrm{b}), \mathrm{PLA}+\mathrm{CE}+\mathrm{T}+\mathrm{CF}(\mathrm{c}), \mathrm{PLA}+\mathrm{CE}+\mathrm{T}+\mathrm{BF}(\mathrm{d})$. The actual porosity values are represented after the abbreviation of the materials within every micrograph.

distribution of cell size is obtained. Also, an increase in the open-cell ratio in the presence of fibres compared to unreinforced PLA foams was expected based on the results of previous studies [20].

\subsection{Crystallinity}

The crystallinity of the PLA foams was examined by DSC method. The first heating runs of the neat PLA foams at three porosity levels are presented in Figure 5. It can be observed that the low porosity PLA foams are almost fully amorphous, which is indicated by the sharp glass transition around $60^{\circ} \mathrm{C}$ and by the broad exothermic peak in the range of 100 and $120^{\circ} \mathrm{C}$ indicating significant cold-crystallisation [21]. The melting of the crystalline phase occurs around $150^{\circ} \mathrm{C}$. Typically two endothermic peaks are visible, at $149^{\circ} \mathrm{C}$ corresponding to melting of the less ordered $\alpha^{\prime}$ crystals, and at $156^{\circ} \mathrm{C}$ corresponding to melting of the thermodynamically more stable $\alpha$

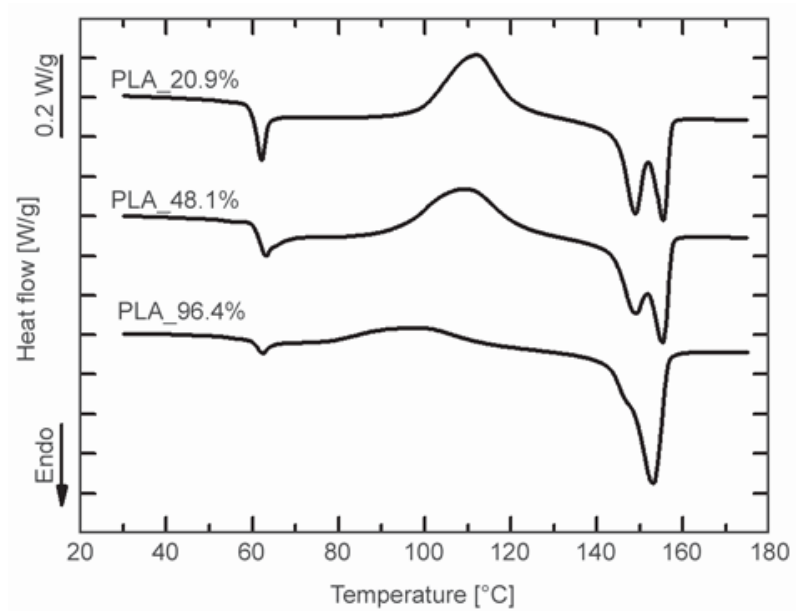

Figure 5. DSC curves of PLA foams of increasing porosity. The actual porosity values are represented after the abbreviation of the materials within the graph.

crystals [22]. In contrast, only a slight cold-crystallization exotherm is observable in the DSC curve of the PLA foam of $96.4 \%$ porosity, indicating notice- 


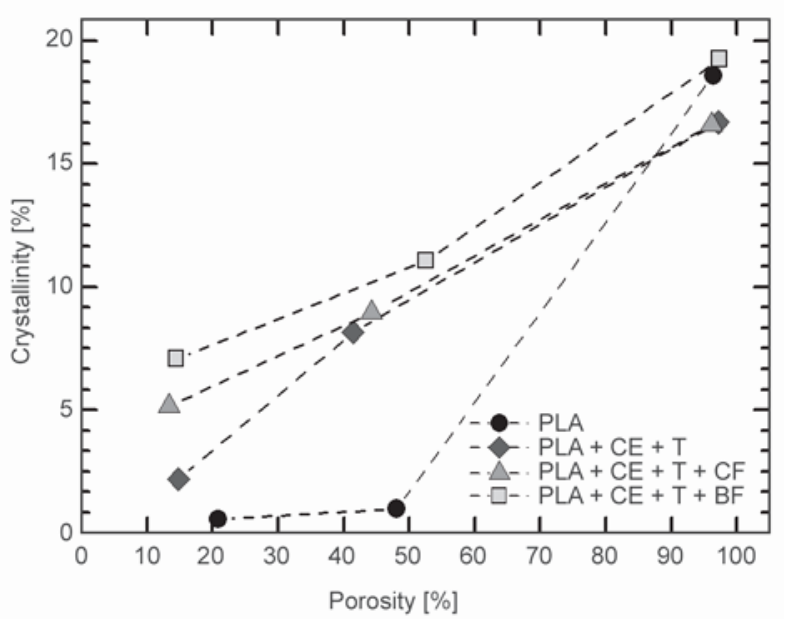

Figure 6. Foam crystallinity as a function of porosity

able inherent crystalline phase in this sample. Based on the dominance of the ordered $\alpha$ crystal form in the highly expanded PLA foam, it can be concluded that its crystallization occurred mainly during processing. Similar trends were observed for the other examined, additive containing PLA foams.

Figure 6 presents the estimated crystallinity versus porosity for the neat and additive containing PLA foams. It can be seen that for the foam samples containing additives the degree of crystallinity increased almost linearly with porosity. It is likely due to the strain-induced crystallization $[9,23]$ and to the plasticizing effect of $\mathrm{CO}_{2}$ which results in the decrease of the temperature of crystallization and formation of more perfect crystalline domains.

The advantageous effect of the used nucleating agents (talc, cellulose and basalt fibre) on the crystallinity is most observable at lower expansion ratios. Accordingly, both natural fibres promoted the nucleation effectively, but the highest degree of crystallinity values were obtained for the basalt fibre reinforced PLA foams. In the case of cellulose fibre reinforcement, it is supposed that the increased dynamic viscosity (Figure 2) and thus the hindrance of molecular chain mobility decreased the crystallization. The high degree of crystallinity is, however, crucial to obtain improved thermo-mechanical properties [24, 25]. The prominent nucleating ability of basalt fibres has been utilized recently by Tábi et al. [26] to obtain crystalline PLA composites of high heat deflection temperatures.

\subsection{Compression strength}

The mechanical performance of the PLA foams, manufactured in this work, has been evaluated based on their compression strength at $10 \%$ deformation. The compression strength of the obtained neat and additive containing highly expanded $(\varepsilon>95 \%)$ PLA foams are indicated in Figure 7. It is clearly visible that without additives the neat PLA foam has low compression strength, about $20 \mathrm{kPa}$. This is expected based on the collapsed cell structure, also observed in Figure $4 \mathrm{a}$, formed as a consequence of the insufficient melt strength. In contrast, the addition of CE and talc promoted the formation of uniform cellstructure, the mechanical resistance of which reaches $100 \mathrm{kPa}$. The compression strength of the talc and CE containing PLA foam deteriorated when $5 \mathrm{wt} \%$ natural fibres were added. This can be explained by the poor adhesion, the lower polydispersity and the increased open-cell ratio evidenced by SEM micrographs (Figure $4 \mathrm{c}$ and d). Another argument can be that cellulose and basalt fibres are too large compared with the cell size to provide efficient reinforcement. Nevertheless, the compression strength of the basalt fibre reinforced PLA foam reaches $40 \mathrm{kPa}$.

\section{Conclusions}

Natural fibre reinforced microcellular PLA composite foams were manufactured by $\mathrm{scCO}_{2}$ assisted foam extrusion process, the same method that could be easily scaled-up even towards real industrial applications. Epoxy functionalized CE and talc were used to improve the foamability of PLA. It was found that the addition of $5 \mathrm{wt} \%$ cellulose or basalt fibres pro-

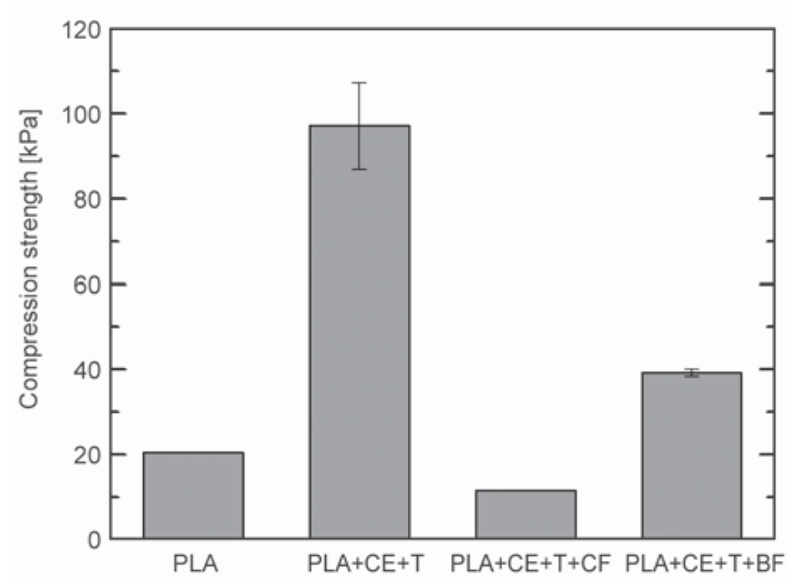

Figure 7. Compression strength of PLA foams 
vides a wider processing window for PLA foam production. Based on the lower applicable temperature profile, a greater degree of crystallinity and improved melt strength could be expected. It was evinced that natural fibres increase the melt viscosity and promote the heterogeneous cell nucleation. As a result, microcellular composite foam structures with porosity higher than $95 \%$ could be obtained. However, due to the fibre distribution and the weak fibre matrix adhesion, the fibre reinforced foams have less uniform cell structure and increased open cell ratio compared to the unreinforced $\mathrm{CE}$ and talc containing foam. Basalt fibres can serve as reinforcement providing improved compression strength comparing to PLA foams. However, the best mechanical performance was achieved without reinforcing fibres, by applying only the combination of $\mathrm{CE}$ and talc. The compression strength of this foam reaches $100 \mathrm{kPa}$. It is believed that further chemical or physical modifications, such as reinforcement and flame retardancy, could promote the market penetration of PLA foams in technical application fields as well.

\section{Acknowledgements}

This work was financially supported by the Hungarian Scientific Research Fund (grant numbers OTKA K112644 and K105257). This paper was supported by the János Bolyai Research Scholarship of the Hungarian Academy of Sciences and by the Italian-Hungarian and the Mexican-Hungarian bilateral agreement of the Hungarian Academy of Sciences. This work is connected to the scientific program of the 'Development of quality-oriented and harmonized $\mathrm{R}+\mathrm{D}+\mathrm{I}$ strategy and functional model at BME' project. This project is supported by the New Széchenyi Development Plan (Project ID: TÁMOP-4.2.1/B-09/1/KMR-2010-0002).

\section{References}

[1] Nofar M., Park C. B.: Poly (lactic acid) foaming. Progress in Polymer Science, 39, 1721-1741 (2014). DOI: $10.1016 /$ j.progpolymsci.2014.04.001

[2] Pilla S., Kim S. G., Auer G. K., Gong S., Park C. B.: Microcellular extrusion-foaming of polylactide with chain-extender. Polymer Engineering and Science, 49, 1653-1660 (2009). DOI: $10.1002 /$ pen.21385

[3] Najafi N., Heuzey M. C., Carreau P. J., Wood-Adams P. M.: Control of thermal degradation of polylactide (PLA)-clay nanocomposites using chain extenders. Polymer Degradation and Stability, 97, 554-565 (2012). DOI: $\underline{10.1016 / \text { j.polymdegradstab.2012.01.016 }}$
[4] Wang J., Zhu W., Zhang H., Park C. B.: Continuous processing of low-density, microcellular poly(lactic acid) foams with controlled cell morphology and crystallinity. Chemical Engineering Science, 75, 390-399 (2012).

DOI: $\underline{10.1016 / \mathrm{j} . c e s .2012 .02 .051}$

[5] Nofar M., Ameli A., Park C. B.: A novel technology to manufacture biodegradable polylactide bead foam products. Materials and Design, 83, 413-421 (2015). DOI: $10.1016 /$ j.matdes.2015.06.052

[6] Nofar M., Ameli A., Park C. B.: Development of polylactide bead foams with double crystal melting peaks. Polymer, 69, 83-94 (2015).

DOI: $10.1016 /$ j.polymer.2015.05.048

[7] Mihai M., Huneault M. A., Favis B. D.: Crystallinity development in cellular poly(lactic acid) in the presence of supercritical carbon dioxide. Journal of Applied Polymer Science, 113, 2920-2932 (2009).

DOI: $10.1002 /$ app.30338

[8] Rachtanapun P., Selke S. E. M., Matuana L. M.: Microcellular foam of polymer blends of HDPE/PP and their composites with wood fiber. Journal of Applied Polymer Science, 88, 2842-2850 (2003).

DOI: $10.1002 / a p p .12170$

[9] Keshtkar M., Nofar M., Park C. B., Carreau P. J.: Extruded PLA/clay nanocomposite foams blown with supercritical $\mathrm{CO}_{2}$. Polymer, 55, 4077-4090 (2014). DOI: $10.1016 /$ j.polymer.2014.06.059

[10] Di Y., Iannace S., Di Maio E., Nicolais L.: Poly(lactic acid)/organoclay nanocomposites: Thermal, rheological properties and foam processing. Journal of Polymer Science Part B: Polymer Physics, 43, 689-698 (2005). DOI: $10.1002 /$ polb.20366

[11] Sauceau M., Fages J., Common A., Nikitine C., Rodier E.: New challenges in polymer foaming: A review of extrusion processes assisted by supercritical carbon dioxide. Progress in Polymer Science, 36, 749-766 (2011). DOI: 10.1016/j.progpolymsci.2010.12.004

[12] Ladin D., Park C. B., Park S. S., Naguib H. E., Cha S. W.: Study of shear and extensional viscosities of biodegradable $\mathrm{PBS} / \mathrm{CO}_{2}$ solutions. Journal of Cellular Plastics, 37, 109-148 (2001)

DOI: 10.1106/72D3-9PX6-7C60-RD2X

[13] Takada M., Hasegawa S., Ohshima M.: Crystallization kinetics of poly(L-lactide) in contact with pressurized $\mathrm{CO}_{2}$. Polymer Engineering and Science, 44, 186-196 (2004).

DOI: $10.1002 /$ pen.20017

[14] Vigh T., Sauceau M., Fages J., Rodier E., Wagner I., Sóti P. L., Marosi G., Nagy Z. K.: Effect of supercritical $\mathrm{CO}_{2}$ plasticization on the degradation and residual crystallinity of melt-extruded spironolactone. Polymers for Advanced Technologies, 25, 1135-1144 (2014). DOI: $10.1002 /$ pat.3367 
[15] Le Moigne N., Sauceau M., Benhyakhlef M., Jemai R., Benezet J-C., Rodier E., Lopez-Cuesta J. M., Fages J.: Foaming of poly(3-hydroxybutyrate-co-3-hydroxyvalerate)/organo-clays nano-biocomposites by a continuous supercritical $\mathrm{CO}_{2}$ assisted extrusion process. European Polymer Journal, 61, 157-171 (2014).

DOI: 10.1016/j.eurpolymj.2014.10.008

[16] Fischer E. W., Sterzel H. J., Wegner G.: Investigation of the structure of solution grown crystals of lactide copolymers by means of chemical reactions. Colloid and Polymer Science, 251, 980-990 (1973).

DOI: $10.1007 /$ BF01498927

[17] Matuana L. M., Diaz C. A.: Study of cell nucleation in microcellular poly(lactic acid) foamed with supercritical $\mathrm{CO}_{2}$ through a continuous-extrusion process. Industrial and Engineering Chemistry Research, 49, 2186 2193 (2010). DOI: $10.1021 /$ ie9011694

[18] Matuana L. M., Faruk O.: Effect of gas saturation conditions on the expansion ratio of microcellular poly(lactic acid)/wood-flour composites. Express Polymer Letters, 4, 621-631 (2010).

DOI: $10.3144 /$ expresspolymlett.2010.77

[19] Bergeret A., Benezet J. C.: Natural fibre-reinforced biofoams. International Journal of Polymer Science, 2011, 569871/1-569871/14 (2011).

DOI: $10.1155 / 2011 / 569871$

[20] Li Q., Matuana L. M.: Foam extrusion of high density polyethylene/wood-flour composites using chemical foaming agents. Journal of Applied Polymer Science, 88, 3139-3150 (2003).

DOI: $10.1002 / a p p .12003$
[21] Tábi T., Sajó I. E., Szabó F., Luyt A. S., Kovács J. G.: Crystalline structure of annealed polylactic acid and its relation to processing. Express Polymer Letters, 4, 659668 (2010).

DOI: $10.3144 /$ expresspolymlett.2010.80

[22] Le Marec P. E., Ferry L., Quantin J-C., Bénézet J-C., Bonfils F., Guilbert S., Bergeret A.: Influence of melt processing conditions on poly(lactic acid) degradation: Molar mass distribution and crystallization. Polymer Degradation and Stability, 110, 353-363 (2014). DOI: $10.1016 /$ j.polymdegradstab.2014.10.003

[23] Garancher J-P., Fernyhough A.: Expansion and dimensional stability of semi-crystalline polylactic acid foams. Polymer Degradation and Stability, 100, 21-28 (2014). DOI: 10.1016/j.polymdegradstab.2013.12.037

[24] Battegazzore D., Bocchini S., Frache A.: Crystallization kinetics of poly(lactic acid)-talc composites. Express Polymer Letters, 5, 849-858 (2011).

DOI: $10.3144 /$ expresspolymlett.2011.84

[25] Petchsuk A., Buchatip S., Supmak W., Opaprakasit M., Opaprakasit P.: Preparation and properties of multibranched poly(D-lactide) derived from polyglycidol and its stereocomplex blends. Express Polymer Letters, 8, 779-789 (2014).

DOI: $10.3144 /$ expresspolymlett.2014.80

[26] Tábi T., Tamás P., Kovács J. G.: Chopped basalt fibres: A new perspective in reinforcing poly(lactic acid) to produce injection moulded engineering composites from renewable and natural resources. Express Polymer Letters, 7, 107-119 (213). DOI: 10.3144/expresspolymlett.2013.11 